\title{
УДК: 316.46
}

https://doi.org/10.33296/2707-0654-9(18)-01

\author{
АРЕФ'СВ СЕРГІЙ \\ доктор економічних наук, професор, \\ професор кафедри підприємництва та бізнесу, \\ Київський національний університет технологій \\ та дизайну, м. Київ, Україна \\ ORCIDiD: https://orcid.org/0000-0003-2184-458X
}

\section{ГЕНЕЗА РОЗВИТКУ ЛІДЕРСТВА В УПРАВЛІННІ ЕКОНОМІЧНИМИ ІНТЕРЕСАМИ ПІДПРИЕМСТВА}

Анотація. Визначено та обгрунтовано, що лідерська компетентність це сукупність його знань, вмінь професійної підготовленості і певні особистісні якості, здатності комунікувати із носіями інших стилів при прийнятті рішень, спрямованих на зміни в стратегіях на означених сегментах ринку, інноваційної модернізації, цифрових платформ. Зазначено, що лідерські якості при поєднанні з управлінськими здібностями дозволяють реалізовувати як власні компетенції, так і органічно задовольняти виявлені економічні інтереси підприємства, забезпечуючи ритмічне i безперервне функціонування, реалізовувати цілі. Виділено характеристики лідера i керівника у певному порівнянні і гуртуючись на функціонуванні підприємства в офіціальних i неофіціальних площинах, тому місце і роль керівника і лідера можуть значно відрізнятись відповідно до ступеня відповідальності за прийняття тих чи інших рішень, які можуть бути орієнтиром при розробці моделі ефективного лідерства. Акцентовано увагу на зміцненні особистісних характеристик лідера при реалізації функції новатора та впровадженні соціально-відповідальної поведінки.

Досліджуючи реалізацію якостей лідера в управлінні економічними інтересами підприємства, доведено, що специфічність економічних інтересів підприємства полягає в їхньому перетинанні, посиленні відповідно до носія, його відношення до процесу діяльності, тобто внутрішнього або зовнішнього середовища, агрегування за рівнями, а також із основними рисами ефективного лідера. Доведено, що специфічність економічних інтересів підприємства полягає в їхньому перетинанні, посиленні відповідно до носія, його відношення до процесу діяльності, тобто внутрішне або зовнішне середовище, агрегування за рівнями, а також із основними рисами ефективного лідера задля нівелювання небезпек. Обгрунтована доцільність інституалізації лідерства і економічних інтересів зацікавлених сторін із застосуванням їх якісного діагностування i моніторингу.

\footnotetext{
(C) Українська інженерно-педагогічна академія

(C) ГО «Школа адаптивного управління сочіально-педагогічними системами»

(C) Apеф'єв C.
} 
Електронне наукове фрахове видання «Адаптивне управління: теорія і практика»

Серія «Економіка»

Випуск 9 (18), 2020

Ключові слова: лідерство, керівник, управління, економічні інтереси, підприємство, розвиток, адаптація, методи керівництва.

Вступ. В умовах турбулентності змін здійснення діяльності підприємствами потребує прийняття управлінських рішень на підставі врахування процесів інтелектуалізації, реалізації концепції соціальновідповідального бізнесу у вибраних конкурентних напрямах. Прискорення темпів неотехнологічного оновлення має спиратись на здібностях і якостях лідера-новатора, що створить переваги як для колективів, так i для підприємства в цілому. Опанування нових компетенцій і задоволення економічних інтересів сторін стає основною передумовою прискореного розвитку в довгостроковому періоді і забезпечить лідерські позиції самого підприємства. Необхідність таких досліджень, накопичення досвіду формування і реалізації лідерських компетенцій особистості і колективу свідчить про актуальність даної статті і проблеми.

Аналіз останніх досліджень і розробок. Проблема висвітлення місця і значення лідерства при функціонуванні підприємств стала предметом дослідження таких вчених, як: И. Адизес, С. Бойко, Л. Борщ, Л. Данченко, А., Доронин, М. Мартненко, М. Мескон, В. Міляєва, С. Нестуля, Г. Старовойтова та ін.

Лідерство розглядалось як здатність здійснювати вплив на окремих осіб і групи, спрямовуючи їх зусилля на досягнення цілей організації [10, с. 464], тобто формувати мотиваційні передумови для ефективної взаємодії членів команди. Також є думка, що саме ефективне лідерство використовує нові додаткові джерела влади і забезпечує ii нові позитивні наслідки: прихильність до організації і готовність до змін [5, с. 357].

В тім, для функціонування українських підприємств поєднання якостей лідера i керівника потребує додаткового опрацювання також 3 позиції виявлення і задоволення економічних потреб стейхолдерів, а також процесу управління з огляду на зміну умов діяльності, динаміку змін у зовнішньому і внутрішньому середовищ і при використанні потенціалу.
(C) Українська інженерно-педагогічна академія
(C) ГО «Школа адаптивного управління сочіально-педагогічними системами»
(C) Ареф'єв C. 
Електронне наукове фрахове видання «Адаптивне управління: теорія і практика»

Серія «Економіка»

Випуск 9 (18), 2020

Формування мети. Основною метою даної наукової роботи $\epsilon$ обгрунтування основних характеристик лідера підприємства у порівняння із керівником та опрацювання гармонізації їх при забезпеченні управління економічними інтересами зацікавлених сторін.

Виклад власного матеріалу. Сучасні процеси інтелектуалізації технологій управління та діяльності підприємства потребують постійної адаптації до змінюваних умов господарювання, активності керівництва в отриманні інформації щодо стану та перспектив зовнішнього середовища задля підтримання впевненості стейхолдерів і трудового колективу у стабільності його перспектив. Прийняття вчасних рішень при неочікуваних господарських ситуаціях вимагає від керівництва поєднувати якості ще і лідера, здатного забезпечити морально-психологічний клімат i створити конструктивні відносини між співробітниками. Слід зазначити, що проблемі як визначення дефініції «лідер», так і його якостям приділено достатньо уваги с точки зору обгрунтування характеристик, різниці та спільного між керівником і лідером на підприємствах, що дозволяє закріпити певну відповідальність при визначенні шляхів розвитку, місця на сегментах ринку, реалізації економічних інтересів.

В тім, існує думка, що ідеального лідера не існує і не може існувати. Однак існує ідеальне лідерство, його забезпечує ефективна команда носіїв взаємодоповнюючих стилів менеджменту: виробник, адміністратор, підприємець, інтегратор [1]. В даному контексті компетентність підтверджується вже не самого лідера, а «компетентністю команди», здатної відповідально і вчасно виконувати стратегічні плани і тактичні завдання для підтримання фінансово-економічних інтересів колективу і зацікавлених осіб. Лідер вже має обрати відповідний до виробничо-господарської діяльності підприємства власний стиль і систему взаємодії (взаємовідносин) із дотичними його відповідальності підрозділами, націлений на формування команд, здатних баз конфліктів сприймати необхідні зміни.

(C) Українська інженерно-педагогічна академія

(C) ГО «Школа адаптивного управління сочіально-педагогічними системами»

(C) Apeф'єв C. 
Електронне наукове фрахове видання «Адаптивне управління: теорія і практика»

Серія «Економіка»

Випуск 9 (18), 2020

Лідерська компетентність це також сукупність його знань, вмінь професійної підготовленості i певних особистісних якостей, здатності комунікувати із носіями інших стилів при прийнятті рішень, спрямованих на зміни в стратегіях на означених сегментах ринку, інноваційної модернізації, цифрових платформ.

Д.М.Кузе та Б.Познер у роботі «Виклик лідерства» доводять, що лідерство є низкою практик, які може опанувати майже кожен, дотримуючись п’яти наступних принципів: ефективні лідери кидають виклик процесам, системам, звичайним способам виконання речей; вони йдуть на ризик, експериментують, генерують ідеї й заохочують інновації, сприяють навчанню і навчаються самі; вони не є задоволеними status quo; лідери надихають на спільне бачення; вони роблять реальними надії та мрії інших; сприяють тому, аби люди побачили неймовірні можливості у майбутньому, повірили у свої мрії та спільність мети; вони розуміють потреби людей та тримають їхні інтереси у серці; лідери, які уможливлюють втілення в життя неймовірних речей, розвивають спроможність інших діяти; вони підтримують тих, хто потребує підтримки, та тих, на кого впливатимуть результати діяльності; вони говорять «ми» і заохочують співпрацю та командну роботу і роблять так, аби інші могли виконувати роботу добре; хороші лідери слугують для інших прикладом; їхня поведінка, ставлення та дії віддзеркалюють їхні переконання та цілі; вони чітко усвідомлюють свої переконання та розуміють, що повагу можна заслужити, якщо дії відповідають переконанням. Вони діють так, як говорять і як очікують від інших; лідери запалюють серця; заохочують просування до мети, незважаючи на складності, втрати, втому; сприяють розумінню того, що шлях $\epsilon$ довгим, але можливим [15].

Функціонування підприємства здійснюється в офіціальних $\mathrm{i}$ неофіціальних площинах, тому місце і роль керівника і лідера можуть значно відрізнятись відповідно до ступеня відповідальності за прийняття тих чи інших рішень. Має місце певна взаємна обумовленість і взаємний зв'язок лідера i 
Електронне наукове фрахове видання «Адаптивне управління: теорія і практика»

Серія «Економіка»

Випуск 9 (18), 2020

керівника підприємства (рис. 1), що дозволяє підкреслити, що задля успішного функціонування та отримання значних результатів діяльності вигідним $\epsilon$ поєднання якостей лідера у керівника. Так, А. Дж. Мерфі зазначає, що спроможність до лідерства проявиться за наявності певної ситуації, тобто ситуація викликає лідера, який повинен стати інструментом вирішення проблеми [9].

В контексті спільного і різного між лідерами і керівниками підприємства слід додати, що керівник офіційно представляє фінансово-економічні, кадровокомпетентністні, інноваційно-інвестиційні, майнові, ринкові інтереси, а лідер діє здебільшого контекстно, тобто здебільшого ситуаційно. В правовому полі також значно відрізняються права та обов'язки керівника, які закріплені в законному порядку (юридично) та наділений встановленою системою санкцій, які закріплені в нормативно-правовому забезпеченні діяльності підприємства.

Також, науковці країн із розвиненою ринковою економікою виокремлюють такі відмінні ознаки лідерів і керівників: керівники шукають сумлінних виконавців, а лідери - однодумців; керівники не вибачають помилок ні собі, ні іншим, а лідери переважно визнають свої помилки і не бояться відкрито вживати необхідних заходів для їх виправлення; керівники вважають, що підлеглі навіть з високою компетенцією неспроможні виконувати роботу без контролю і вказівок згори. В основі роботи лідера лежить принцип рівності; керівники намагаються створити собі позитивний імідж, хоча це неможливо через конфліктну природу відносин між керівниками і підлеглими. Лідери цінують повагу колег, наділені репутацією людини 3 високою етикою, 3 повагою ставляться до працівників, захищають їхні інтереси. Працівники вдячні лідерам і всіляко їх підтримують [13, с. 179].

(C) Українська інженерно-педагогічна академія

(C) ГО «Школа адаптивного управління сочіально-педагогічними системами»

(C) Apеф'єв C. 
Взаємна обумовленість і взаємний зв'язок лідера і керівника підприємства

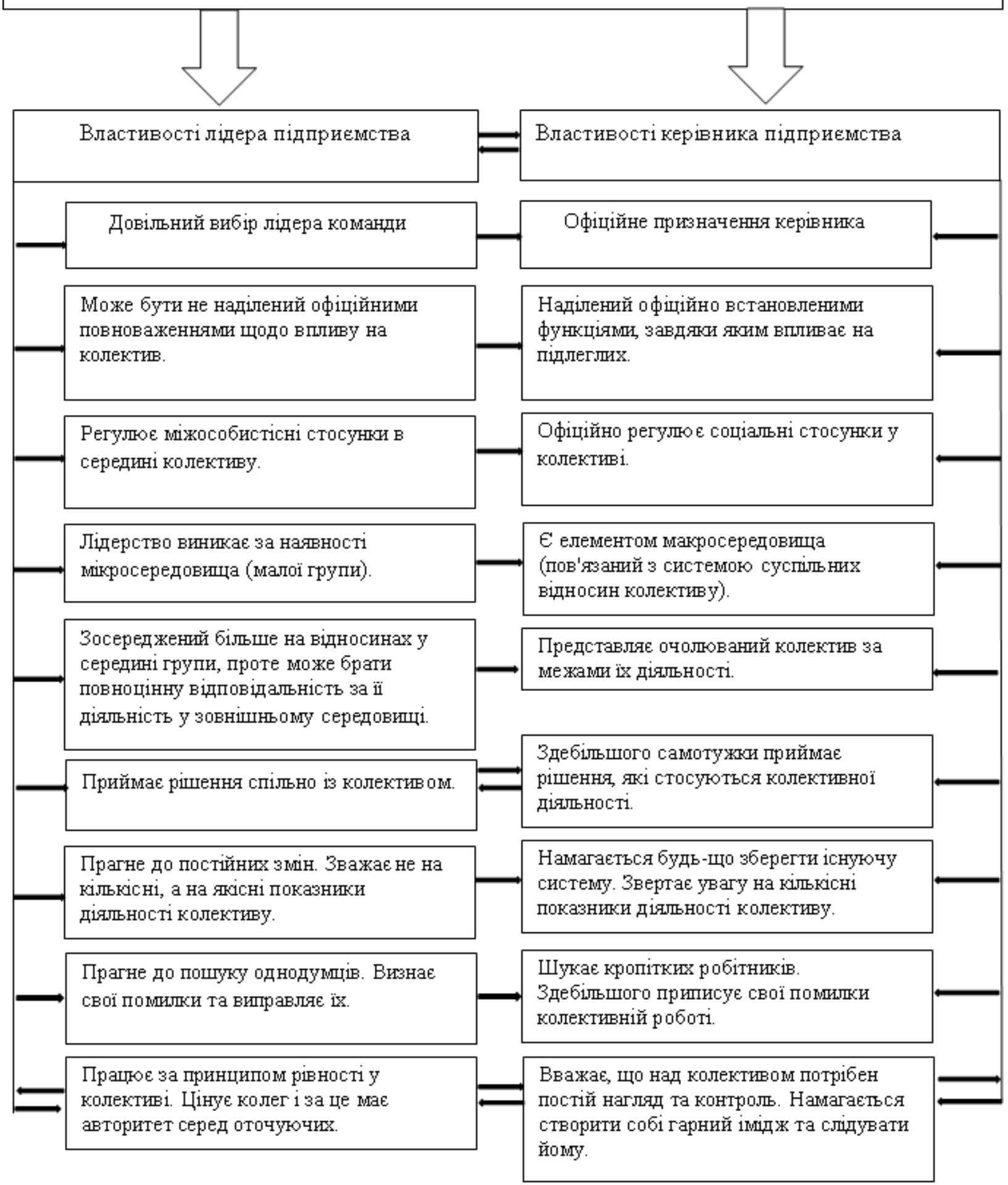

Рис. 1 Взаємна обумовленість і взаємний зв'язок лідера і керівника підприємства

Удосконалено автором на підставі: [4, 6, 7, 12]. 
Електронне наукове фрахове видання «Адаптивне управління: теорія і практика»

Серія «Економіка»

Випуск 9 (18), 2020

Провідною ідеєю підвищення ролі лідерів в управлінні економічними інтересами є об'єктивна необхідність максимально можливого поєднання якостей лідера i керівника, що стимулюватиме колективи до ефективного виконання покладених на них функцій i виконання посадових інструкцій. Визначені характеристики лідера i керівника грунтуються на рамкових принципах, що сприяє визначенню стилю керівництва (табл. 1), спираючись на специфічних особливостях управління при інформатизації, цифровізації діяльності на всіх можливих рівнях організаційної структури.

Таблиця 1

\section{Порівняльна характеристика стилів керівництва [3, 10, 13]}

\begin{tabular}{|c|c|c|c|}
\hline & Авторитарний стиль & Демократичний стиль & Ліберальний стиль \\
\hline $\begin{array}{l}\text { Владні } \\
\text { повноваження }\end{array}$ & $\begin{array}{l}\text { Зосередження всієї } \\
\text { влади і } \\
\text { відповідальності в } \\
\text { руках лідера }\end{array}$ & $\begin{array}{l}\text { Делегування } \\
\text { повноважень } 3 \\
\text { утриманням ключових } \\
\text { позицій у лідера }\end{array}$ & $\begin{array}{l}\text { Зняття лідером з себе } \\
\text { відповідальності, } \\
\text { зречення влади на } \\
\text { користь групи }\end{array}$ \\
\hline Прийняття рішень & $\begin{array}{l}\text { Прерогатива лідера у } \\
\text { встановленні цілей і } \\
\text { виборі засобів їх } \\
\text { досягнення }\end{array}$ & $\begin{array}{l}\text { Прийняття рішень } \\
\text { поділено за рівнями на } \\
\text { основі участі }\end{array}$ & $\begin{array}{l}\text { Надання можливості } \\
\text { самоуправління в } \\
\text { бажаному для групи } \\
\text { режимі }\end{array}$ \\
\hline Комунікації & $\begin{array}{l}\text { Комунікаційні потоки } \\
\text { йдуть переважно } \\
\text { зверху }\end{array}$ & $\begin{array}{l}\text { Комунікації } \\
\text { здійснюються активно у } \\
\text { двох напрямках }\end{array}$ & $\begin{array}{l}\text { Комунікації } \\
\text { відбуваються } \\
\text { переважно по } \\
\text { горизонталі }\end{array}$ \\
\hline Сильні сторони & $\begin{array}{l}\text { Увага до терміновості } \\
\text { і порядку, можливість } \\
\text { прогнозування } \\
\text { результатів }\end{array}$ & $\begin{array}{l}\text { Посилення особистих } \\
\text { зобов’язань при } \\
\text { виконанні роботи через } \\
\text { участь в управлінні }\end{array}$ & $\begin{array}{l}\text { Дозволяє почати } \\
\text { справу без втручання } \\
\text { лідера }\end{array}$ \\
\hline Слабі сторони & $\begin{array}{l}\text { Стримується } \\
\text { індивідуальна } \\
\text { ініціатива }\end{array}$ & $\begin{array}{l}\text { Необхідний тривалий } \\
\text { час для з’ясування } \\
\text { позицій і узгодження }\end{array}$ & $\begin{array}{l}\text { Без втручання лідера } \\
\text { група може втратити } \\
\text { швидкість і напрямок } \\
\text { руху }\end{array}$ \\
\hline
\end{tabular}

Для того, щоб успішно здійснювати управлінські функції, сучасному керівнику потрібно вміти вести за собою підлеглих. Виступаючи сьогодні в ролях керуючого і новатора, керівник насамперед виявляє себе як лідер. У кожній конкретній трудовій групі діє індивід, до якого прислухаються i

\footnotetext{
(C) Українська інженерно-педагогічна академія

(C) ГО «Школа адаптивного управління сочіально-педагогічними системами»

(C) Apеф'єв C.
} 
Електронне наукове фрахове видання «Адаптивне управління: теорія і практика»

Серія «Економіка»

Випуск 9 (18), 2020

придивляються інші люди, він впливає на навколишніх головним чином за двома соціально-психологічними каналами:

а) за каналом авторитету (члени групи визнають перевагу лідера перед іншими в силу його положення, досвіду, майстерності, освіти тощо);

б) за каналом харизматичних властивостей (людяність, ввічливість, моральність). У реальному житті все це виливається в добровільне визнання винятковості лідера, що характеризується в неухильному наслідуванні, копіюванні його дій і в цілому його поведінки [7, с. 26];

в) за каналом інноватора як особи, здатної для просування нового товару на ринок, формування споживчого попиту, отримання прибутку;

г) соціальної відповідальності внутрішньої i зовнішньої. Щодо внутрішньої - вона проявляється у стабільності виплат заробітної плати, забезпеченні охорони здоров’я робітників, безпеки праці, створення умов для розвитку працівника через підвищення кваліфікації, здійснення допомоги у певних ситуаціях тощо. До зовнішньої слід віднести заходи щодо охорони середовища, відповідальність перед споживачами в аспекті виробництва якісних товарів, взаємодія з органами місцевої влади, благодійність та інші.

Гармонізація як характеристика діяльності підприємства досить рідко використовується в управлінській практиці та теоретичних розробках. Ці питання розвиваються емпірично, стихійно та мало враховуються при підготовці та прийнятті управлінських рішень як 3 поточної діяльності підприємства, так і з питань його розвитку [17, с. 2].

Постійне випередження змін зовнішнього середовища підприємством на всіх конкурентних напрямах майже не можливо, тому доцільно більше уваги приділяти таким сегментам, де воно займає лідерські позиції. При такому підході можна забезпечити ефективність діяльності всього підприємства через вчасне застосування розроблених сценаріїв та забезпечення економічних інтересів як менеджерів, робітників, стейкхолдерів, так i формування конкурентної позиції по інших товарах та послугах.

\footnotetext{
(C) Українська інженерно-педагогічна академія

(C) ГО «Школа адаптивного управління сочіально-педагогічними системами»

(C) Apeф'єв C.
} 
Електронне наукове фрахове видання «Адаптивне управління: теорія і практика»

Серія «Економіка»

Випуск 9 (18), 2020

Специфічність економічних інтересів підприємства полягає в їхньому перетинанні, посиленні відповідно до носія, його відношення до процесу діяльності, тобто внутрішнє або зовнішнє середовище, агрегування за рівнями, а також із основними рисами ефективного лідера (рис. 2). Сталість системи економічних інтересів залежить від стабільності і стійкості діяльності, стадії життєвого циклу, масштабу і галузі діяльності підприємства, кількості конкретних переваг, їхніх джерел і зайнятих сегментів ринку, екологічних наслідків функціонування.

Основні риси ефективного
лідера:
компетентність;
відповідальність;
рішучість;
здатність до новаторства;
комунікабельність у
зовнішньому і внутрішньому
середовищі;
освідченість у відносинах і
процесах;
впливовість в трудовому
колективі і професійній
спільноті;
підтримуе кількісні і якісні
показники;
професіоналіз в галузі
ділльності підпримства;
здатність збалансувати
стратегію і тактику;
порядність;
спонукання до розвитку;
самовпевненість;
харизматичність.

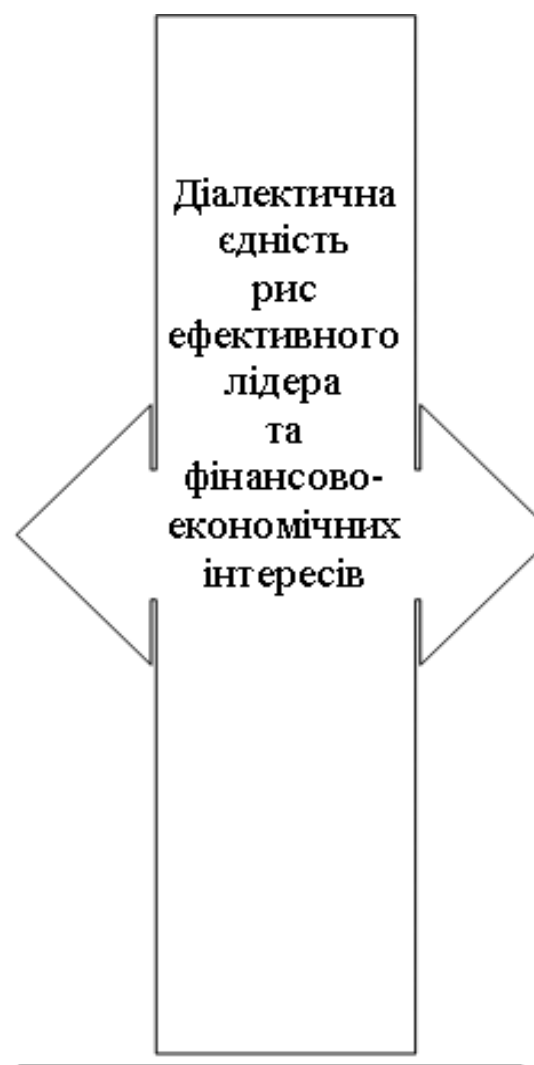

Основні фінансово-економічні інтереси промислового підприємства:

1) зростання його ринкової вартості та збільшення присутності на ринку;

2) максимізацію прибутку;

3) забезпеченість інвестиціями для стійкого розвитку промислового підприємства, включаючи його фінансову систему; 4) забезпечення фінансовими ресурсами для ефективного ведення виро6ничо-

господарської діяльності;

5) оптимізацію відрахувань до бюджету;

6) збільшення ринкової

вартості;

7) виконання комерційноі та розрахункової дисципліни;

8) зростання вартості акцій.

Гармонізація інтересів колектива, економічнах інтересів піпприсмства $\mathrm{i}$ с тейхолдерів

Рис. 2. Гармонізація інтересів колективу, економічних інтересів підприємства i стейхолдерів $[6,9,14]$.

(C) Українська інженерно-педагогічна академія

(C) ГО «Школа адаптивного управління сочіально-педагогічними системами»

(C) Apеф'єв C. 
Електронне наукове фрахове видання «Адаптивне управління: теорія і практика»

Серія «Економіка»

Випуск 9 (18), 2020

Це також відображається у складових поточних економічних інтересах підприємства та їхніх характеристиках, які деталізують та стануть основою для обгрунтування системи показників при оцінюванні ефективності використання ресурсів при комерційно-виробничій діяльності і збалансованості задоволення певних складових.

Висновки. Поява або посилення означеної складової економічних інтересів можуть поєднуватись повність (або частково) при появі нових чинників діяльності підприємства та можливим розв’язанням суперечностей об’єктів та суб’єктів щодо результатів діяльності, використання і розподілу ресурсів, темпів зміни вартості активів, здатності до самофінансування.

Підприємство потребує належної інституалізації лідерства і економічних інтересів зацікавлених сторін із застосуванням їх якісного діагностування i моніторингу. Конструктивність формування їхньої єдності сприятиме вчасному прийняттю рішень щодо вибору напрямів розвитку підприємства, нівелювання загроз не виконання виробничої, комерційної, платіжної дисципліни. Деструктивний вплив опору змінам колективів і їхнє гальмування не дозволить реалізувати економічні інтереси учасників і знизить вірогідність успішного управління процесами.

\section{Використана література:}

1. Адизес И. Развитие лидеров: Как понять свой стиль управления и эффективно общаться с носителями иных стилей / Ицхак Калдерон Адизес ; Пер.с англ. М.: Альпина Бизнес Букс, 2008. 259 с.

2. Бойко С. Політичне лідерство в Україні: генезис і динаміка розвитку. Політичний менеджмент. 2011. № 6. С. 91-100.

3. Борщ Л.В. Економічні засади та інноваційні технології формування й використання лідерського потенціалу. Економіка та право. 2012. № 12. С. 2028.

4. Грицяк I. A. Twinning як механізм співробітництва між державними службовцями України та Європейського Союзу. Стратегічна панорама. 2007. № 1. С. 114-120.

5. Доронін А. В., Козирєва М. М. Якісний розвиток функцій керівника колективу. Коммунальное хозяйство городов. Сб. научн. трудов. Вып. 87. К.: Техніка. 2009. С. 357-366. 
Електронне наукове фрахове видання «Адаптивне управління: теорія і практика»

Серія «Економіка»

Випуск 9 (18), 2020

6. Данченко Л. Г., Гордина В. В. Сучасні стратегічні моделі типів керівництва та лідерства в організації. Молодий вчений. 2015. № 11 (26). С. 5255 .

7. Козак К. Б. Роль лідерства в системі управління персоналом на підприємстві. Економіка харчової промисловості. 2013. № 3 (19). С. 24-28.

8. Логунова М. Соціально-психологічні аспекти управлінської діяльності. К. : Центр сприяння інституціонального розвитку державної служби, 2006.196 с.

9. Лугова В. М., Єрмоленко О. А. Напрями розвитку лідерської компетентності керівників українських підприємств. Проблеми економіки. 2012. № 1. C. 64-67.

10. Мескон М. Основы менеджмента / [М. Мескон, М. Альберт, Ф. Хедоури]; общ. ред. и вступ. ст. Л. И. Евенко; Акад. нар. хоз-ва при Правительстве Рос. Федерации. М.: Дело, 1992. 702 с.

11. Міляєва В.Р. Розвиток лідерського потенціалу в процесі формування управлінської компетентності керівників навчальних закладів. Вісник Національної академії Державної прикордонної служби України. 2014. № 1. C.34-40.

12. Нестуля C.I. Емоційне лідерство - новий напрям у лідерології XXI ст. Науковий вісник Полтавського університету споживчої кооперачії Украӥни. Серія: Економічні науки. 2010. № 40. С.77-83.

13. Орбан-Лембрик Л. Е. Психологія управління: посібник. К. : Академвидав, 2003. 568 с.

14. Прилепа Н. В. Лідерство в системі управління підприємством. Вісник Хмельницького національного університету. 2019. № 5. С. 184-187.

15. Розвиток лідерства / [Л. Бізо, І. Ібрагімова, О. Кікоть та ін.]. К.: Проект «Реформа управління персоналом на державній службі», 2012. 400 с.

16. Старовойтова Г.М. Харизматичне лідерство як предмет соціальнофілософського розгляду. Вісник Донецького національного університету економіки і торгівлі ім. М. Туган-Барановського. Серія: Гуманітарні науки. 2012. № 2. C.84-90.

17. Шаріпова О.С., Надьон Г.О. Гармонізація діяльності як процес забезпечення економічної безпеки підприємства. Управління проектами та розвиток виробнищтва. 2012. № 1(41). С. 1-6.

\section{References}

1. Adizes I. Razvitie liderov: Kak ponyat svoy stil upravleniya i effektivno obshchatsya s nositelyami inykh stiley / Itskhak Kalderon Adizes ; Per.s angl. M.: Alpina Biznes Buks, 2008. 259 s.

2. Boiko S. Politychne liderstvo v Ukraini: henezys i dynamika rozvytku. Politychnyi menedzhment. 2011. № 6. S. 91-100. 
Електронне наукове фрахове видання «Адаптивне управління: теорія і практика»

Серія «Економіка»

Випуск 9 (18), 2020

3. Borshch L.V. Ekonomichni zasady ta innovatsiini tekhnolohii formuvannia y vykorystannia liderskoho potentsialu. Ekonomika ta pravo. 2012. № 12. S. 20-28.

4. Hrytsiak I. A. Twinning yak mekhanizm spivrobitnytstva mizh derzhavnymy sluzhbovtsiamy Ukrainy ta Yevropeiskoho Soiuzu. Stratehichna panorama. 2007. № 1. S. 114-120.

5. Doronin A. V., Kozyrieva M. M. Yakisnyi rozvytok funktsii kerivnyka kolektyvu. Kommunalnoe khoziaistvo horodov. Sb. nauchn. trudov. Vыр. 87. K.: Tekhnika. 2009. S. 357-366.

6. Danchenko L. H., Hordyna V. V. Suchasni stratehichni modeli typiv kerivnytstva ta liderstva v orhanizatsii. Molodyi vchenyi. 2015. № 11 (26). S. 52-55.

7. Kozak K. B. Rol liderstva v systemi upravlinnia personalom na pidpryiemstvi. Ekonomika kharchovoi promyslovosti. 2013. № 3 (19). C. 24-28.

8. Lohunova M. Sotsialno-psykholohichni aspekty upravlinskoi diialnosti. K. : Tsentr spryiannia instytutsionalnoho rozvytku derzhavnoi sluzhby, 2006.196 s.

9. Luhova V. M., Yermolenko O. A. Napriamy rozvytku liderskoi kompetentnosti kerivnykiv ukrainskykh pidpryiemstv. Problemy ekonomiky. 2012. № 1. S. 64-67.

10. Meskon M. Osnovy menedzhmenta / [M. Meskon, M. Albert, F. Khedouri]; obshch. red. i vstup. st. L. I. Yevenko; Akad. nar. khoz-va pri Pravitelstve Ros. Federatsii. M.: Delo, 1992. 702 s.

11. Miliaieva V.R. Rozvytok liderskoho potentsialu v protsesi formuvannia upravlinskoi kompetentnosti kerivnykiv navchalnykh zakladiv. Visnyk Natsionalnoi akademii Derzhavnoi prykordonnoi sluzhby Ukrainy. 2014. № 1. S.34-40.

12. Nestulia S.I. Emotsiine liderstvo - novyi napriam u liderolohii XXI st. Naukovyi visnyk Poltavskoho universytetu spozhyvchoi kooperatsii Ukrainy. Seriia: Ekonomichni nauky. 2010. № 40. S.77-83.

13. Orban-Lembryk L. E. Psykholohiia upravlinnia: posibnyk. K. : Akademvydav, 2003. $568 \mathrm{~s}$.

14. Prylepa N. V. Liderstvo v systemi upravlinnia pidpryiemstvom. Visnyk Khmelnytskoho natsionalnoho universytetu. 2019. № 5. S. 184-187.

15. Rozvytok liderstva / [L. Bizo, I. Ibrahimova, O. Kikot ta in.]. K.: Proekt «Reforma upravlinnia personalom na derzhavnii sluzhbi», 2012. $400 \mathrm{~s}$.

16. Starovoitova H.M. Kharyzmatychne liderstvo yak predmet sotsialnofilosofskoho rozghliadu. Visnyk Donetskoho natsionalnoho universytetu ekonomiky $i$ torhivli im. M. Tuhan-Baranovskoho. Seriia: Humanitarni nauky. 2012. № 2. S.8490 .

17. Sharipova O.S., Nadon H.O. Harmonizatsiia diialnosti yak protses zabezpechennia ekonomichnoi bezpeky pidpryiemstva. Upravlinnia proektamy ta rozvytok vyrobnytstva. 2012. № 1(41). S. 1-6.

(C) Українська інженерно-педагогічна академія

(C) ГО «Школа адаптивного управління сочіально-педагогічними системами»

(C) Apеф'єв C. 


АРЕФБЕВ СЕРГЕЙ
доктор экономических наук,
профессор кафедры предпринимательства и бизнеса,
Киевский национальный университет технологий и дизайна, г. Киев, Украина

\section{ГЕНЕЗИС РАЗВИТИЯ ЛИДЕРСТВА В УПРАВЛЕНИИ ЭКОНОМИЧЕСКИМИ ИНТЕРЕСАМИ ПРЕДПРИЯТИЯ}

Аннотация. Определено и обосновано, что лидерская компетентность это совокупность его знаний, умений профессиональной подготовленности и определенные личностные качества, способности коммуницировать с носителями других стилей при принятии решений, направленных на изменения в стратегиях на указанных сегментах рынка, инновационной модернизации, цифровых платформ. Отмечено, что лидерские качества при сочетании с управленческими способностями позволяют реализовывать как собственные компетенции, так и органично удовлетворять выявленные экономические интересы предприятия, обеспечивая равномерное и непрерывное функционирование, реализовывать цели. Выделены характеристики лидера и руководителя в определенном сравнении и опираясь на функционирование предприятия в официальных и неофициальных плоскостях, поэтому место и роль руководителя и лидера могут значительно отличаться в соответствии со степенью ответственности за принятие тех или иных решений, которые могут быть ориентиром при разработке модели эффективного лидерства. Акцентировано внимание в укреплении личностных характеристик лидера при реализации функции новатора и внедрении социально-ответственного поведения. Исследуя реализацию качеств лидера в управлении экономическими интересами предприятия, доказано, что специфичность экономических интересов предприятия заключается в их пересечении, усилении соответствии с носителя, его отношение к процессу деятельности, то есть внутренней или внешней среде, агрегирования по уровням, а также с основными чертами эффективного лидера. Доказано, что специфичность экономических интересов предприятия заключается в их пересечении, усилении соответствии с носителя, его отношение к процессу деятельности, то есть внутреннее или внешнее среду, агрегирования по уровням, а также с основными чертами эффективного лидера для нивелирования угроз. Обоснована целесообразность институализации лидерства и экономических интересов заинтересованных сторон с применением их качественного диагностирования и мониторинга.

Ключевые слова: лидерство, руководитель, управление, экономические интересы, предприятие, развитие, адаптация, методы управления.

\footnotetext{
(C) Українська інженерно-педагогічна академія

(C) ГО «Школа адаптивного управління сочіально-педагогічними системами»

(C) Apеф 'єв C.
} 
AREFIEV SERHII,

Dr. Sc. (Econ.), Associate Professor,

Professor Department of entrepreneurship and business,

Kyiv National University of Technologies and Design, Kyiv, Ukraine

\title{
GENESIS OF LEADERSHIP DEVELOPMENT IN MANAGEMENT OF ECONOMIC INTERESTS OF THE ENTERPRISE
}

\begin{abstract}
It is determined and substantiated that leadership competence is a set of his knowledge, skills and certain personal qualities, ability to communicate with carriers of other styles when making decisions aimed at changes in strategies in certain market segments, innovative modernization, digital platforms. It is noted that leadership qualities in combination with managerial abilities allow to realize both own competences, and organically to satisfy the revealed economic interests of the enterprise providing rhythmic and continuous functioning, to realize the purposes. The characteristics of the leader and the leader in a certain comparison and focusing on the functioning of the enterprise in formal and informal areas, so the place and role of the leader and the leader can differ significantly according to the degree of responsibility for making decisions that can guide the development of effective leadership. Emphasis is placed on strengthening the personal characteristics of the leader in the implementation of the function of innovator and the introduction of socially responsible behavior. Examining the implementation of the qualities of a leader in the management of economic interests of the enterprise, it is proved that the specificity of economic interests of the enterprise lies in their intersection, strengthening according to the carrier, its relation to the process, internal or external environment, aggregation by levels. . It is proved that the specificity of economic interests of the enterprise lies in their intersection, strengthening according to the carrier, its relation to the process of activity, internal or external environment, aggregation by levels, as well as the main features of an effective leader. The expediency of institutionalization of leadership and economic interests of stakeholders with the use of their quality diagnosis and monitoring is substantiated.
\end{abstract}

Key words: leadership, manager, management, economic interests, enterprise, development, adaptation, leadership methods. 